\title{
Effects of Gender, Mathematics Anxiety and Achievement Motivation on College Students' Achievement in Mathematics
}

\author{
Dr. Ajogbeje, Oke James (Corresponding Author) \\ Principal Lecturer, Department of Mathematics, \\ College of Education, Ikere-Ekiti, Ekiti State, Nigeria \\ E-mail: ajogbejeoke@yahoo.com ; ojajogbeje@gmail.com \\ Cell-phone Number: +2348137779336; +2347058844342 \\ Dr. Borisade, Fidelis Tunde \\ Principal Lecturer, Department of Primary Education Studies \\ College of Education, Ikere-Ekiti, Ekiti State, Nigeria \\ E-mail: drborisade@gmail.com \\ Cell-phone Number: +2348037717321 \\ Aladesaye, Charles Ademuyiwa \\ Lecturer, Department of Mathematics, \\ College of Education, Ikere-Ekiti, Ekiti State, Nigeria \\ E-mail: charles.aladegbaye@yahoo.com \\ Phone Number: +2348033928020 \\ Ayodele, Oludolapo Bolanle \\ Lecturer, Department of Mathematics, \\ College of Education, Ikere-Ekiti, Ekiti State, Nigeria \\ E-mail: dolapo123@yahoo.com \\ Phone Number: +2348051278238
}

Received: 11-03- 2013

doi:10.7575/aiac.ijels.v.1n.1p.15
Accepted: 01-05- 2013

Published: 01-07- 2013

URL: http://dx.doi.org/10.7575/aiac.ijels.v.1n.1p.15

\begin{abstract}
The urge to excel or perform maximally in mathematics varies from individual to individual because achievement motivation is often developed or learnt during socialization and learning experiences. The study examined the relationship between College of Education students' achievement motivation and mathematics achievement, correlation coefficient between mathematics anxiety and college students' achievement motivation as well as mathematics anxiety and mathematics achievement. The sample, 268 College of Education students offering mathematics as one of their subject combination, was selected using purposive sampling techniques. Three research instruments namely: Mathematics Anxiety Scale (MAS), Achievement Motivation Scale (AMS) and Mathematics Achievement Test (MAT) were used to collect data for the study. Data collected for the study were analyzed using correlational analysis and ANOVA. The results showed that a significantly low negative correlation coefficient existed between mathematics anxiety and mathematics achievement. There is a negative and significant correlation coefficient between mathematics anxiety and achievement motivation. Similarly, a positive and significant correlation coefficient also exists between achievement motivation and mathematics achievement. Based on the findings of the study, it was recommended that mathematics teachers should adopt activity based strategies and conducive learning environment in order to reduce college students' anxieties in mathematics learning.
\end{abstract}

Keywords: Mathematics anxiety, achievement motivation, mathematics achievement, gender, college students

\section{Introduction}

Nigeria, in her quest for technological breakthrough, has not only made Mathematics a compulsory subject in the curriculum of the primary and secondary schools in her educational system (FGN, 2004), it is also a pre-requisite to the study of science courses in her Colleges and Universities and a gateway to scientific and technological breakthroughs. A rudimentary knowledge of Mathematics is seen as a sine qua non if citizens are to effectively function in present day society. In spite of the exalted position which mathematics occupied in the educational system of Nigeria, there is a public outcry and deep concern by parents, educators, employers of labour and government functionaries over the increasing failure rates of students in mathematics at both internally and externally conducted examinations. One of the 
frequently mentioned variables affecting college students' performance in mathematics is anxiety, boredom and their inability to comprehend the importance of mathematics either in professional or personal life. Research studies have shown that family pressure or parental attitudes, learning styles, self-concept, self-esteem, negative attitudes toward mathematics, avoidance of mathematics, teachers' attitudes, ineffective teaching styles, negative school experiences and low degree of achievement in mathematics (Bursal \& Paznokas, 2006; Cook, 1998; Hadfield \& McNeil, 1994; Ma \& Xu, 2004; Norwood, 1994; Reynolds, 2001; Uusimaki \& Nason, 2004; Williams, 1994; Woodard, 2004) ) are among the concepts and constructs related to mathematics anxiety.

According to Parham (1988) anxiety is a psychological state consisting fear, worry, dread and tenseness and Özer (1997) opined that an individual faced with this situation experiences fear and anxiety. Similarly, Byrd (1982) and Lazarus (1974) opined that mathematics anxiety is a fear state while D'Ailly \& Bergering (1992), Fennema and Sherman (1976), Hadfield and Trujillo (1999), Levine (1995), Ma (2003) as well as Richardson and Suinn (1972) argued that mathematics anxiety is a feeling of stress and fear or apprehension which hinders mathematical problemsolving and calculation in both regular and academic life. According to Miller and Mitchell (1994), mathematics anxiety revolves round a set of circumstances in which students experienced fears as a result of many years of painful experiences with mathematics while Ashcraft and Faust (1994) also contended that mathematics anxiety is the feeling of tension, helplessness, mental dis-organization and dread that students experienced when manipulation of numbers, shapes and solutions to mathematical problems are required.

Bessant (1995) stated that mathematics anxiety has three dimensions namely: (1) mathematics examination anxiety, (2) numeric anxiety, and (3) abstraction anxiety while Brush (1981) claimed that mathematics anxiety is a content-oriented test anxiety. Harris and Harris (1987) classified reasons adduced for mathematics anxiety into three namely: (i) studentrelated, (ii) teacher-related, and (iii) subject-related reasons while Hadfield and McNeil (1994) classified these reasons into environmental reasons (experiences in mathematics classes and personality traits of mathematics teachers), mental reasons (high abstraction and logic in mathematics content), and individual reasons (self-esteem, mathematics attitudes, self confidence in mathematics, learning styles in mathematics, and previous experiences related to mathematics). Greenwood (1984) postulated that the major cause of mathematics anxiety could found in teaching methodologies and mathematics classes which did not encouraged reasoning and understanding while Jackson and Leffingwell (1999), Lazarus (1974) as well as Steele and Arth (1998) reported that mathematics anxiety begins to take root in elementary and secondary grades and could also be linked with prior experience with formal instruction in mathematics. Hembree (1990) found mathematics anxiety among high school students while Betz (1978), Bitner, Austin and Wadlington (1994) and Tobias (1990) also found mathematics anxiety among college students. The findings of the study carried out by Jackson and Leffingwell (1999) further revealed that $16 \%$ of the respondents in their study experienced mathematics anxiety in mathematics instruction as early as grades 3 and 4 .

The reported cases of mathematics anxiety among elementary school students might be the results of parent or teachers' social learning and their negative perceptions of mathematics. A significant predictive strength according to Vann (1993) exists between mathematics anxiety in children and mathematics anxiety in mothers while Geçtan (1995) also reported that children of parents with excessive expectations whose love and acceptance is based on how well children live up to these expectations tend to have high degree of anxiety. Ma and Xu (2004); Norwood (1994), Reynolds (2001), Satake and Amato (1995), Townsend, Moore, Tuck and Wilton (1998).all reported that low grades or failure in mathematics is capable of exasperating the existing level of mathematics anxiety in students and might lead to extreme or deep hatred for mathematics. Hopko, McNeil, Lejuez, Ashcraft, Eifert, and Riel (2003) as well as Ajogbeje (2012a) observed that students with mathematics anxiety are prone to mistakes in solving mathematical problems and such mistakes often lead to lower grades in mathematics and might in turn increases students mathematics anxiety level. Students might also perceive their performance in mathematics as a measure of their self-worth and a possible reason for losing favour or care from their parents and teachers. Hence, a student with excessive worries might develop a negative attitude toward mathematics which is usually expressed as "I can't do mathematics" or "I hate mathematics."

Another variable affecting college students' mathematics anxiety is achievement motivation which Atkinson (1977) defines as the required tendency to start off a task, working to attain success and avoid underachievement. McClelland (1962) claimed that individuals with high achievement need to take reasonable risks preferably activities that can be achieved easily which in turn provides inner satisfaction as a result of the successes achieved while a low need for achievement could be associated with a sense of low competence, low expectations, and orientation toward failure (Atkinson, 1977; Nicholls, 1976). Another factor believed to be a contributor to mathematics anxiety is gender. Gierl and Bisanz (1995) reported that gender has no significant contribution to mathematics anxiety. In a study carried out by Hunsley and Flessati (1988), they reported that female subjects score significantly higher than male subjects in mathematics anxiety while Campbell and Evans (1997) also reported that female students exhibit more mathematics anxiety in secondary school and in college than male students. However, in a research work carried out by Flessati and Jameison (1991) as follow up to one earlier carried out by Hunsley and Flessati (1988), they contended that a response bias explanation cannot account for the gender differences in mathematics anxiety and the fact that females are more self-critical of mathematics anxiety and their performances in mathematics is not sufficient to explain the gender difference in mathematics anxiety.

Current research works on mathematics anxiety such as Satake and Amato (1995) as well as Ma (1999) revealed that the relationship between mathematics anxiety and mathematics achievement is significant. Ma (1999) reported that once mathematics anxiety takes shape, its relationship with mathematics achievement is consistent across grade levels. 
Ashcraft and Faust (1994) also reported that a highly mathematics anxious individuals will be less fluent in computation, less knowledgeable about mathematics, and less likely to have discovered special strategies and relationships within the mathematics domain. Finally, Ajogbeje (2012), Ajogbeje and Olagoke (2012) as well as Greenwood (1984) opined that the problems with mathematics anxiety would not go away unless mathematics teachers can create an active learning environment and applied the problem solving process to the teaching of mathematics.

\section{Objectives the Study}

The main objectives of this study in specific terms are to:

1. Examine the difference between college students' achievement motivation and mathematics achievement according to mathematics anxiety levels

2. Investigate the relationships between mathematics anxiety and college students' achievement motivation as well as mathematics anxiety and college students' mathematics achievement.

\section{Research Questions}

The following research questions were generated to guide the study:

1. Is there any difference in the anxiety level of male and female college students toward mathematics?

2. Is there any difference between college students' achievement motivation and mathematics achievement according to mathematics anxiety level?

3. Is there any relationship between (i) mathematics anxiety level and college students' achievement motivation, and (ii) mathematics anxiety level and college students' mathematics achievement?

\section{Research Hypotheses}

Based on the research questions, the following null hypotheses were formulated and tested for significant at $\mathrm{p}<0.05$.

1. There is no significant difference in the anxiety level of male and female students toward mathematics.

2. There was no significant difference between college students' achievement motivation and achievement in mathematics when they were classified according to mathematics anxiety levels

3. There was no significant correlation between (i) mathematics anxiety level and college students' achievement motivation, and (ii) mathematics anxiety level and college students' achievement in mathematics.

\section{Research Method}

The sample for the study consisted of 268 students [116 males and 152 females] drawn from first year students who offered mathematics as one of their teaching (either as major or minor) subjects. Three research instruments namely: Mathematics Anxiety Scale (MAS), Achievement Motivation Scale (AMS) and Mathematics Achievement Test (MAT) were used for data collection. The MAS was adapted from Alexander and Martray (1989) who used an abbreviated version of the Mathematics Anxiety Rating Scale (MARS). The scale used in this study contained 12 items with 3 subscales namely: (i) Mathematics Test Anxiety, that is, the fear of preparing or sitting for mathematics test with 4items; (ii) numerical task anxiety, that is, execution of numerical operations or problems related anxiety with 5 items; and (iii) mathematics course anxiety, that is, anxiety related to the learning and study of mathematics in the class with 3items. Each item on the scale represented an anxiety provoking situation and respondents decided on the level of anxiety aroused by each situation by selecting one out of four available options ("not at all anxious", "only a little anxious", "fairly anxious", or "very anxious"). Mathematics anxiety score was calculated by adding the individual scores from all the items together. The scoreable marks range between 12 and 48. Participant anxiety levels are categorized into low, moderate and high level of anxiety using percentiles. Participants who scored between $33 \%$ and $67 \%$ were considered as moderate while the low and high anxiety levels consisted of participants in the lower $33 \%$ and upper $33 \%$ of the distribution respectively.

The Achievement Motivation Scale (AMS) consisting of 14 items developed by Umay (2002) was adopted for the measurement of achievement motivation of the participants in this study. An internal reliability coefficient of 0.82 was obtained for the scale. Similarly, the Mathematics Achievement Test (MAT) consists of 50 multiple objective questions, with five options A-E and is based on six cognitive levels (that is knowledge, comprehension, application, analysis, synthesis and evaluation). The test items are scored manually with each correct answer attracting one mark while a wrong answer attracts zero. A student level of achievement is taken as his/her total test score. A student's t-test statistic was used to test for significant difference between the genders mean scores of mathematics anxiety and mathematics achievement. F-test was also used in determining the significant difference among groups while correlational analysis was used to assess the correlation coefficients between the variables.

\section{Results}

The data collected for the study were analyzed using percentages, mean, standard deviation, Analysis of Variance (ANOVA) and correlational analysis. the results of this study are presented as shown below.

The percentage distribution of college students on mathematics anxiety level are shown in Table 1. 
Table 1: Percentage distribution of college students on mathematics anxiety groups

\begin{tabular}{lllllllll}
\hline \multirow{2}{*}{ Gender } & Low & \multicolumn{3}{c}{ Moderate } & \multicolumn{3}{c}{ High } & \multicolumn{3}{c}{ Total } \\
\cline { 2 - 9 } & $\mathrm{N}$ & $\%$ & $\mathrm{~N}$ & $\%$ & $\mathrm{~N}$ & $\%$ & $\mathrm{~N}$ & $\%$ \\
\hline Male & 40 & 14.93 & 48 & 17.91 & 28 & 10.45 & 116 & 43.28 \\
Female & 48 & 17.91 & 69 & 25.75 & 35 & 13.06 & 152 & 56.72 \\
Total & 88 & 32.84 & 117 & 43.66 & 63 & 23.50 & 268 & 100 \\
\hline
\end{tabular}

A cursory look at Table 1 shows that the percentage distribution of college students on mathematics anxiety levels. $32.84 \%$ of the sampled college students has Low Mathematics Anxiety (14.93\% Male and 17.91\% Female), the Moderate Mathematics Anxiety group has 43.66\% made up 17.91\% Male and 25.75\% Female while the High Mathematics Anxiety group has $23.5 \%$ of the college students made up of $10.45 \%$ Male and $13.06 \%$ Female. It is evident from Table 1 that the highest percentages of college students fall into the moderate group. The group also recorded the highest number or percentage of female college students

Table 2: Mean scores of male and female groups in mathematics anxiety scores

\begin{tabular}{lllllll}
\hline Groups & $\mathrm{N}$ & Mean & SD & df & T & Sig. T \\
\hline Male & 116 & 35.12 & 9.07 & 266 & 6.85 & 0.001 \\
Female & 152 & 38.96 & 9.84 & & & \\
\hline
\end{tabular}

The mean scores of male and female college students were compared using t- test. From Table 2 the $t$ calculated is significant showing that the observed difference in college students' mathematics anxiety scores is in favour of the female group since the female students scored significantly higher than male students.

Table 3: Mean Scores of college students according to mathematics anxiety groups in mathematics achievement and achievement motivation

\begin{tabular}{llll}
\hline Mathematics Anxiety Group & & Achievement & Motivation \\
\cline { 2 - 4 } & $\mathrm{N}$ & Mean & Mean \\
\hline High & 63 & 38.10 & 42.55 \\
Moderate & 117 & 49.33 & 46.83 \\
Low & 88 & 55.69 & 51.62 \\
Total & 268 & 47.73 & 47.00 \\
\hline
\end{tabular}

Table 3 shows the number of college students in each anxiety group and their mean scores on AMS and MAT. From Table 3, it was revealed that the mean for Low Mathematics Anxiety group on mathematics achievement and achievement motivation are 55.69 and 51.62 respectively. The mean for Moderate Mathematics Anxiety group on mathematics achievement and achievement motivation are 49.33 and 46.83 respectively while the mean for High Mathematics Anxiety group on mathematics achievement and achievement motivation are 38.1 and 42.55 respectively. The overall mean stood at 47.73 and 47.00 for mathematics achievement and achievement motivation respectively. The table also revealed that the mean scores of low and moderate mathematics anxiety groups were above the overall average score in mathematics achievement while only low mathematics anxiety group was above the overall average score in achievement motivation.

Table 4: ANOVA table for mathematics achievement scores according to mathematics anxiety

\begin{tabular}{llllll} 
groups & \multicolumn{1}{l}{} & \\
\hline Source of Variation & df & MS & F-cal & F-tab & Remark \\
\hline Between Groups & 2 & 2624.90 & 4.46 & 3.04 & Sig. \\
Within Groups & 265 & 589.15 & & & \\
\hline
\end{tabular}

Table 4 contains the information on the summary of the one-way ANOVA results of mathematics anxiety levels on mathematics achievement. Table 4 revealed that the mean mathematics achievement scores of low, moderate and high mathematics anxiety groups were significantly different $\mathrm{F}(2,265)=4.46, \mathrm{P}<0.05$. The data was further subjected to Tukey's HSD tests which further revealed that the mean differences in mathematics achievement test between the low 
and high mathematics anxiety groups, the low and moderate mathematics anxiety groups and the moderate and high mathematics anxiety groups were statistically significant.

Table 5: ANOVA table for achievement motivation scores according to mathematics anxiety

\begin{tabular}{llllll} 
groups & \multicolumn{1}{l}{} & & \\
\hline Source of Variation & df & MS & F-cal & F-tab & Remark \\
\hline Between Groups & 2 & 596.92 & 14.97 & 3.04 & Sig. \\
Within Groups & 265 & 23.91 & & & \\
\hline
\end{tabular}

Table 5 above reveals a significant difference in college students' achievement motivation among the three mathematics anxiety groups. The obtained $\mathrm{F}$ - ratio is $\mathrm{F}(2,265)=14.97, \mathrm{P}<0.05$. This shows that the mean achievement motivation scores of low, moderate and high mathematics anxiety groups were statistically significant. The data was further subjected to Tukey's HSD tests which further revealed that the mean differences in achievement motivation between the low and high mathematics anxiety groups, the low and moderate mathematics anxiety groups and the moderate and high mathematics anxiety groups were statistically significant.

Table 6: Intercorrelational matrix mathematics anxiety, achievement motivation and mathematics achievement

\begin{tabular}{llll}
\hline & $\begin{array}{l}\text { Mathematics } \\
\text { Anxiety }\end{array}$ & $\begin{array}{l}\text { Achievement } \\
\text { Motivation }\end{array}$ & $\begin{array}{l}\text { Mathematics } \\
\text { Achievement }\end{array}$ \\
\hline Mathematics Anxiety & 1.00 & & \\
Achievement Motivation & $-0.83^{*}$ & 1.00 & 1.00 \\
Mathematics Achievement & $-0.34^{*}$ & $0.28^{*}$ &
\end{tabular}

A cursory look at Table 6 showed the correlation coefficient matrix for the three variables. It indicated that there is a negative and significant relationship (-0.34) between mathematics anxiety and college students' mathematics achievement at 0.05 level of significance. It is also observed from the correlation coefficient matrix that a negative and significant relationship (-0.83) exists between mathematics anxiety and college students' achievement motivation. Table 6 also reveals that a positive and significant correlation coefficient $(r=0.28)$ exists between college students' achievement motivation and mathematics achievement. However, mathematics anxiety and college students' mathematics achievement as well as college students' achievement motivation and mathematics achievement indicated a low correlation coefficient of -0.34 and 0.28 respectively. The correlation coefficients observed in the table ranged between -0.83 and 0.28 .

\subsection{Discussion}

Findings of this study indicate that a higher percentage of college students studied have moderate mathematics anxiety while the remaining college students either have low mathematics anxiety or high mathematics anxiety towards mathematics. The study further shows that female high mathematics anxiety group stands at $13.06 \%$ while that of male high mathematics anxiety group stands at $10.45 \%$. This result corroborates the reported findings of Ramprasad (2003) that disparities exist between male and female high mathematics anxiety groups. The result also confirms the previously reported findings of the effect of gender on mathematics anxiety at elementary and secondary level (Wigfield \& Meece, 1988); seventh, eighth and ninth grade level (Eccles \& Jacobs, 1986) and college level (Ashcraft \& Faust, 1994; Bander \& Betz,1981; Betz, 1978; Brush, 1985; Hembree, 1990). However, the result contradicts the findings of Richardson and Suinn (1972) which reported a no significant difference between male and female students mathematics anxiety level. The result also contradicts the reported findings of Rajni (2009) which stated that masculine group among female exhibits disparity in mathematics anxiety with the high masculine group showing lower mathematics anxiety while the low masculine group shows high mathematics anxiety. However, Rajni (2009) further reported that there is no significant disparity between the two feminine females' subgroups in her study.

The findings of this study also show that college students with high mathematics anxiety scored significantly low in mathematics achievement while the effect of mathematics anxiety on achievement motivation was also significant. This implies that college students with low mathematics anxiety scored significantly higher than college students with moderate or high mathematics anxiety while college students with moderate anxiety scored significantly higher than college students with high mathematics anxiety. These findings agreed with the findings of Betz (1978) and Tapia (2004).

Finally, the findings of the study also revealed a negative and significant relationship between mathematics anxiety and mathematics achievement as well as mathematics anxiety and achievement motivation. These findings corroborate the 
findings of Betz (1978), Ma (1999) and Woodard (2004) with all of them reporting a negative relationship between mathematics anxiety and achievement in mathematics. The high correlation coefficient of $(-0.83)$ though negative between mathematics anxiety and achievement motivation was expected since college students with high anxiety would be less motivated in relation to mathematics achievement.

\section{Conclusion}

The results of this study show that mathematics anxiety is an important variable that cannot be ignored in the teaching and learning of mathematics. Therefore, mathematics teachers ought to adopt activity based strategies in the teaching and learning of mathematics in order to reduce college students' mathematics anxiety level. In learning mathematics there is need to use methods, strategies and materials which make the learning of mathematics very active, investigative and adventurous. According to Ajogbeje (2012), Ajogbeje and Olagoke (2012) as well as Greenwood (1984) the problems associated with mathematics anxiety would not go away until mathematics teachers start applying the problem solving process or technique in the teaching of mathematics.

\subsection{Recommendations}

Based on the findings of this study, it is recommended that parents and teachers are to set positive role models and lend supportive hand to their wards in order to foster competence in mathematics. Effective use of counseling and guidance services could have preventive functions by aiding college students with effective study skills and helping them cope with feelings such as fear of failure. Teaching strategies which create a relaxed environment in which students do not feel threatened and students are made to participate actively in the learning process should be adopted in the teaching of mathematics. Feedback, remediation and extra tuition sessions where need be should be provided for college students in order to overcome difficulties and challenges they might be facing in learning mathematics. The researchers are of the opinion that the poor performance of students in mathematics at different levels of our educational system could be explained in terms of teachers allowing students difficulties to accumulate for so long that, at a certain stage, everything about mathematics makes no meaning.

\section{References}

Ajogbeje, O. J. (2012). Path-analytic model and the effect of some teaching strategies on variables affecting achievement in junior secondary school mathematics in ondostate. Unpublished Ph. D. Thesis, Ekiti State University, Ado-Ekiti, Nigeria.

Alexander, L. and Martray, C. (1989). The development of an abbreviated version of the Mathematics anxiety rating scale. Measurement and Evaluation in Counseling and Development. 22(3), 143-150.

Ashcraft, M. \& Faust, M. (1994). Mathematics anxiety and mental arithmeticperformance: Anexploratory investigation. Cognition and Emotion, 8(2), 97-125

Atkinson, J. W. (1977).Motivation for achievement. In T. Blass (Ed.), Personality variables in social behavior. (Pp. $47-$ 67). Hillsdale, N.J.: Lawrence Erlbaum.

Bander, R. S., \& Betz, N. E. (1981). The relationship of sex and sex role to trait and Situational specific anxiety types. Journal of Research in Personality. 15(3), 312-322.

Bessant, K. C. (1995). Factors associated with types of mathematics anxiety in college students. Journal for Research in Mathematics Education.26, 327-345.

Betz, N. (1978). Prevalence, distribution, and correlates of mathematics anxiety incollegestudents.Journal of Counseling Psychology. 25(5), 441-448.

Bitner, J., Austin, S., \&Wadlington, E. (1994). A comparison of mathematics anxietyintraditionalandnon-traditional developmental college students.Research andTraining inDevelopmentalEducation.10(2), 35-43.

Brush, L. R. (1981).Some thoughts for teachers in mathematics anxiety.Arithmetic

Teacher.29,37-39.

Bursal, M. \&Paznokas, L. (2006). Mathematics anxiety and pre-service elementary teachers' confidence to teach mathematics and science. School Science and Mathematics.106(4),173-180.

Butterworth, B. (1999). The Mathematical Brain.London: Macmillan.

Byrd, P. (1982).A descriptive study of mathematics anxiety: Its nature and antecedents.Unpublisheddoctoral dissertation, Indiana University, Bloomington.

Campbell, K., \& Evans, C. (1997). Gender issues in the classroom: A comparison of Mathematics anxiety. Education. 117(3), 332-339.

Cook, R. P. (1998). An exploration of relationship between mathematics anxiety levelsand perceptuallearning style of adult learners in community college setting.DissertationAbstracts InternationalSection A: Humanities and SocialSciences.58(10-A), 3801.

D’Ailly, H. \&Bergering, A. J. (1992). Mathematics anxiety and mathematics avoidance behaviour: Avalidation study of two factors. Educational and Psychological Measurement.52(2), 369-378. 
Eccles, J. S., \& Jacobs, J. E. (1986). Social forces shape mathematics attitudes and performance. Journalof Women in Culture and Society. 11, 367-380.

Fennema,E\& Sherman, J.A. (1976).Fennema-Sherman mathematics attitude scales: Instruments designed to measure attitudes toward the learning of mathematics byfemalesand males.Catalogof Selected Documents in Psychology. 6(2), 31.

Fitzgerald, S. M. (1997).The relationship between anxiety and statistics achievement: A meta-analysis. Unpublished doctoral dissertation, University of Toledo, Toledo, $\mathrm{OH}$.

Flessati, S. L., \&Jameison, J. (1991). Gender differences in mathematical anxiety: An artifact of response bias? Lakehead University, Thunder Bay, Ontario, 3, 303-312.

Furner, J. \& Duffy, M. L. (2002). Equity for all students in the new millennium: Disabling mathematics anxiety. Intervention in School and Clinic, 38(2), 67-74.

Gectan, E. (1995). Psychodynamic psychiatryand abnormal behaviours. Istanbul: Remzi Kitabevi.

Gierl, M. \&Bisanz, J. (1995). Anxieties and attitudes related to mathematics in grades 3 and 6. Journal of Experimental Education. 63(2), 139-159.

Greenwood, J. (1984). My anxieties about mathematics anxiety. Mathematics Teacher.77, 662-663.

Hadfield, O. D., \& McNeil, K. (1994).The relationship between Myers-Briggs personality type and mathematics anxiety among pre-service elementary teachers. Journal of InstructionalPsychology.21, 375-384.

Hadfield, O. D. \& Trujillo, K. M. (1999). Tracing the roots of mathematics anxiety through in-depth interviews with pre-service elementary teachers. College Student Journal. 33(2).

Harris, A., \& Harris, J. (1987). Reducing mathematics anxiety with computer assisted instruction. Mathematics and Computer Education.21, 16-24.

Hansley, J., \&Flessati, S.L. (1988). Gender and mathematics anxiety: The role of mathematics related experiences and opinions. Anxiety Research. 1, 215-224.

Hembree, R. (1990).Thenature, effect and relief of mathematics anxiety. Journal for Research in Mathematics Education. 21(1), 33-46.

Hopko, D. R., McNeil, D. W., Lejuez, C. W., Ashcraft, M. H., Eifert, G. H. \& Riel, J. (2003). The effects of anxious responding arithmetic and lexical decision task performance. Journal of Anxiety Disorders. 17(6), 647-665.

Jackson, C.D., \&Leffingwell, R. J. (1999). The role of instructors in creating Mathematics anxiety in students from kindergarten through college. Mathematics Teacher. 92(7), 583-586.

Kazelskis, R. (1999). Some dimensions of mathematics anxiety: A factor analysis across instruments. Educational and Psychological Measurement. 58(4), 623-634.

Lazarus, M., \& Averill, J. R. (1972). Emotions and cognition: with special reference to anxiety. In C. D. Spielberger (Ed.), Anxiety: Current trends in theory and research.(pp. 242-283).NewYork: Academic.

Lazarus, M. (1974).Mathephobia: Some personal speculations.National Elementary Principal.53, 16-22.

Levine, G. (1995). Closing the gender gap: Focus on mathematics anxiety. Contemporary Education. 67(1), 42-45.

Ma,X.(1999). A meta-analysis of the relationship between anxieties toward mathematicsand achievement in mathematics. Journal for Research in mathematicsEducation.30(5),520-540.

Ma, X. (2003). Effect of early acceleration of students in mathematics on attitude toward mathematics and mathematics anxiety. Teachers College Record. 105(3), 438-464.

Ma, X. \&Xu, J. (2004).The causal ordering of mathematics achievement: A longitudinal panel analysis. Journal of Adolescence.27(2), 165-179.

McClelland, D. C. (1962). Business drive and national achievement. Harvard Business Review.40,99-112.

Miller, L.D., \& Mitchell, C.E. (1994).Mathematics anxiety and alternative methods of evaluation. Journal of Instructional Psychology. 21, 353-358.

Murayama, K., \& Elliot, A. J. (2009). The joint influence of personal achievement goals and classroom goal structures on achievement-relevant outcomes. Journal ofEducationalPsychology.101, 432-447.

Nicholls, J. G. (1976). Effort is virtuous, but it is better to have ability: Evaluation responses to perception of ability and effort. Journal of Research in Personality.10, 306-315.

Norwood, K.S. (1994). The effects of instructional approach on mathematics anxiety and achievement. School Science and Mathematics. 94, 248-254.

Ozer, K. (1997). Anxiety.Istanbul: Mart Matbaas1.

Parham, C. (1988). Psychology. Ohio: South-Western Publishing.

Rajni (2009).Mathematics anxiety and cross gender identity in young adult males and females. Unpublished Master of Philosophy (Psychology) thesis, Thapar University,Patiala. 
Ramprasad, R. (2003). Mathematics anxiety and achievement in mathematics.Unpublished Master of Arts (Education) thesis, McGill University.

Reglin, G. L. (1990). The effects of individualized and cooperative computer assisted instruction on mathematics achievement and mathematics anxiety for prospective teachers. Journal of Research on Computing in Education. 22(2), 404-414.

Reynolds, M. (2001).The relationship between mathematics anxiety and motivation: $A$

pathanalysis. Retrieved July 02, 2012, from http://tigersystem.net/area2002/viewproposaltext.asp?propID=2786

Richardson, F. C., \& Suinn, R. M. (1972). The mathematics anxiety rating scale: psychometricdata. Journal of Counseling Psychology. 19, 551-554.

Satake, E \& Amato, P. P. (1995). Mathematics anxiety and achievement among Japanese elementary school students. Educational and Psychological Measurement. 55(6), 1000-1007.

Steele, E., \&Arth, A. (1998).Lowering anxiety in the mathematics curriculum. Education Digest.63(7),18-24.

Stuart, V. (2000).Mathematics curse or mathematics anxiety?Teaching Children Mathematics.6(5),330-350.

Tapia, M. (2004).The relationship of mathematics anxiety and gender. Academic Exchange Quarterly.8(2)

Tobias, S. (1990). Mathematics anxiety: An update. NACADA Journal. 10(1), 47-50.

Townsend, M. A. R., Moore, D. W., Tuck, B. F. \& Wilton, K. M. (1998). Self-concept and anxiety in university students studying social science statistics within a co-operative learning structure. Educational Psychology. 18(1), 4155.

Uusimaki, L. \&Nason, R. (2004). Causes underlying pre-service teachers' negative beliefs and anxieties about mathematics. Proceedings of the 28th Conference of the International Group for the Psychology of Mathematics Education, 4, 369-376.

Vann, B. D. N. (1993). Mathematics anxiety: Parental anxiety as it relates to anxiety in children. Project Dissertations and Theses, 53(08) DAI-A.(Publication No.AAT9237315).

Wigfield, A., \&Meece, J. L. (1988). Mathematics anxiety in elementary and secondaryschool students. Journal of Educational Psychology. 80, 210-216.

Williams, J. (1994). Anxiety measurements construct validity and test performance. Measurement and Evaluation in Counseling and Development. 27(1), 302-308.

Woodard, T. (2004). The effects of mathematics anxiety on post-secondarydevelopmentalstudents asrelated to achievement, gender and age, Inquiry, 9(1). 